- FINANSE I PRAWO FINANSOWE.

- Journal of Finance and Financial Law

Wrzesień/September 2017 • vol. 3(15): 11-26

http://dx.doi.org/10.18778/2391-6478.3.15.02

\title{
APOTEOZA CHCIWOŚCI NA RYNKACH FINANSOWYCH W WYBRANYCH FILMACH FABULARNYCH
}

\author{
Krzysztof Borowski \\ Instytut Bankowości i Ubezpieczeń Gospodarczych \\ Szkoła Główna Handlowa w Warszawie
}

\begin{abstract}
Streszczenie
Współcześnie, w edukacji ekonomicznej, zwłaszcza w Europie Zachodniej i USA, coraz większego znaczenia nabiera wykorzystanie filmów fabularnych do ilustracji: określonych zjawisk i procesów gospodarczych, jak również zachowań inwestorów oraz finansowych i, społecznych i psychologicznych konsekwencji tych zachowań. $W$ artykule omówione zostały fragmenty wybranych filmów fabularnych, zagranicznych i polskich, które odnoszą się do chciwości inwestorów na rynkach finansowych lub też dotyczą ich stosunku do pieniędzy. Fragmenty tych filmów, jak i innych obrazów mogą zostać wykorzystane w procesie dydaktycznym jak i w czasie specjalistycznych kursów z szeroko rozumianych finansów.
\end{abstract}

Słowa kluczowe: edukacja ekonomiczna, rynek finansowych, chciwość, film w procesie edukacji.

JEL Class: G10, G19. 


\section{WPROWADZENIE}

Zjawiska społeczne, w tym również ekonomiczne zachodzące we współczesnym świecie znajdują swoje odzwierciedlenie zarówno w literaturze jak i sztuce. Filmy ${ }^{1}$ są nie tylko tworem wyobraźni reżyserów, ale prezentują dylematy etyczne i wyzwania, z którymi muszą się zmierzyć menedżerowie, właściciele czy pracownicy organizacji. Z kolei wydarzenia zachodzące na światowych rynkach finansowych inspirują reżyserów światowego kina do uwiecznienia ich w kręconych przez siebie obrazach.

W trakcie prowadzenia wykładu istnieje możliwość łatwego odwołania się do konkretnych scen ze znanych filmów w celu uzmysłowienia czy też przywołania słuchaczom określonych faktów lub zdarzeń. W związku z tym, z punktu widzenia wykładowców, powstaje pytanie czy zagadnienia poruszane $\mathrm{w}$ filmach o problematyce finansowej mogą być pomocne w procesie edukacji studentów studiów ekonomicznych, a zwłaszcza w specjalności rynki finansowe?

Uczucia rządzące inwestorami na rynkach finansowych to głównie: chciwość, strach oraz złość. To pierwsze jest przyczyną poszukiwania przez inwestorów wyższych stóp zwrotu niż stopy zwrotu z lokat bankowych. Jest ono także odpowiedzialne za rozwój ducha przedsiębiorczości, co można utożsamiać z koncepcją homo oeconomicus, według której człowiek jest istotą działająca racjonalnie i zawsze dążącą do maksymalizacji osiąganych zysków i dokonującą wyborów ze względu na wartość ekonomiczną rezultatów tych wyborów. Jednak w pewnych przypadkach, nadmierna chciwość może prowadzić wręcz do samozagłady jednostki. Strach jest uczuciem zdecydowanie silniejszym, którego skutki stają się doskonale widoczne w czasie załamań cen aktywów na rynkach finansowych, kiedy inwestorzy prześcigają się w wyprzedawaniu instrumentów finansowych, doprowadzając tym samym do dramatycznych zniżek cen walorów. Niekiedy uczestnicy rynków przeprowadzają transakcje w złości, wzburzeni, pod wpływem emocji. Po upływie pewnego czasu, żałują podjętych w ten sposób decyzji inwestycyjnych, które nie znajdują żadnego uzasadnienia w analizie fundamentalnej czy technicznej. W konsekwencji prowadzą do osiągnięcia przez inwestorów niższych od pierwotnie zakładanych stóp zwrotu.

Celem artykułu jest ukazanie sposobów prezentacji chciwości w wybranych filmach fabularnych (z pominięciem filmów dokumentalnych ${ }^{2}$ ), rządzącej inwe-

${ }^{1} \mathrm{~W}$ dalszej części artykułów filmy kinowe jak i telewizyjne (głównie seriale) nie będą rozróżniane, a dla obu tych kategorii używane będzie pojęcie film.

${ }^{2}$ Jednym z podstawowych celów filmów dokumentalnych jest przedstawienie pewnego zagadnienia ekonomicznego. Natomiast w przypadku filmów fabularnych widzowie muszą jednocześnie zapoznać się z wieloma wątkami, nie tylko tymi o tematyce zarządczej czy finansowej, jak to ma miejsce $w$ filmach dokumentalnych. W filmach fabularnych tematy ekonomiczne przemieszane są $\mathrm{z}$ innym tak, jak ma to miejsce $\mathrm{w}$ życiu. $\mathrm{Z}$ kolei $\mathrm{w}$ filmach dokumentalnych tematyka 
storami na rynkach finansowych, a także konsekwencji czynów popełnianych przez inwestorów pod wpływem tego uczucia. Przedstawione w artykule sposoby prezentacji chciwości mogą zostać wykorzystane w procesie edukacji studentów studiów ekonomicznych lub podczas specjalistycznych kursów z szeroko rozumianych finansów. W podobny sposób wykładowcy mają możliwość wykorzystania określonych scen lub wręcz całych filmów w czasie nauczania wybranych teorii ekonomii lub finansów.

W artykule przyjęta została teza, że sposoby ukazania uczucia chciwości, stosowane $\mathrm{w}$ filmach fabularnych mogą być skutecznym środkiem wykorzystywanym w nauczaniu przedmiotów z szeroko rozumianej problematyki finansowej na uczelniach wyższych. We współczesnym, zdigitalizowanym świecie, prawdziwym wyzwaniem dla wykładowców staje się znalezienie nowych metod nauczania, praktycznie niewykorzystywanych w uczelniach polskich, które w znacznym stopniu podniosłyby dydaktyczną wartość wykładanego przedmiotu. Co prawda podręczniki prezentują teoretyczne podstawy wykładanych koncepcji i teorii, ale odpowiedzialność za atrakcyjne przekazanie wiedzy, leży już w gestii prowadzących. Wiele źródeł oferuje czytelnikom studia przypadków czy też odwołuje się do faktów, jednakże pomimo tego, iż przekazują one wiarygodne informacje, przypadki te czy fakty mogą wydawać się sztuczne dla studenta.

Artykuł składa się z dwóch części: pierwsza część stanowi teoretyczne uzasadnienie wykorzystania filmów w procesie nauczaniu na uczelni wyższej, część druga przedstawia omówienie uczucia chciwości w wybranych filmach fabularnych (bez seriali) poświęconych tematyce rynków finansowych. W przypadku tematyki filmowej przegląd nakręconych filmów pełni również rolę literatury przedmiotu. $Z$ kolei informacje dotyczące reżyserii, daty światowej premiery i producenta zostały uzyskane ze strony internetowej filmweb.pl.

\section{PRZEGLĄD LITERATURY - FILMY JAKO ZASÓB WIEDZY W NAUCZANIU PRZEDMIOTÓW FINANSOWYCH}

W literaturze przedmiotu dominuje podejście sugerujące wykorzystanie filmów, jako metody wzbogacenia stosowanych metod nauczania [Mixton 2010: 110113; Braun 2011: 181-194 a także Sexton 2006: 406-417]. Niektóre opracowania specjalizują się w opisie całych kursów opartych na projekcji filmów fabularnych [Leet i Houser 2003: 326-332] lub też proponują metodę przybliżenia różnic kulturowych za pomocą filmów [Cardon 2010: 150-165]. Jednak według Parkera filmy mogą być wykorzystywane w edukacji przedmiotów humani-

ekonomiczna wydaje się być odseparowana od innych, istotnych dla decydentów wątków. Ponadto trudno jest stworzyć atrakcyjny film dokumentalny, w przeciwieństwie do fabularnego, oddziałujący również na emocje widzów. 
stycznych i socjologicznych [Parker 2009: 129-134]. Zaś Berger i Pratt [1998: 1817-1824] uważają, że filmy wynoszą studentów poza ich własne środowisko, pozwalając im w ten sposób obserwować przebieg procesów teoretycznych w praktyce. Wielu badaczy dowodziło przydatności stosowania filmów fabularnych w edukacji finansowej następujących przedmiotów: komunikacja w biznesie [Berger i Pratt 1998: 1817-1824], zachowania organizacji i podstawy zarządzania [Serey 1992: 374-399 oraz Bumbus 2005: 792-816], przywództwo [Buchanan i Huczynski 2004: 312-323], finanse przedsiębiorstw [Nofsinger 1995: 118-122], etyka w biznesie [McAdams i Duclose 1999: 57-67 oraz Gaiacalone i Jurkiewicz 2001: 79-87], różnice międzykulturowe [Mallinger i Rossy 2003: 608-617], podejmowanie decyzji strategicznych [Buchanan i Huczynski 2004: 312-323], ekonomia [Sexton 2006: 406-417 oraz Leet i Houser 2003: 326-332] oraz teoria gier [Dixit 2005: 205-220].

Według Baya i Feltona [2012: 159] filmy koncentrują się głównie na propagowaniu celów poznawczych takich jak:

- poddawanie analizie różnych procesów poznawczych,

- zachęcanie do nabycia określonej wiedzy,

- poddawanie analizie dylematów etycznych,

- angażowanie emocji studentów w procesie uczenia się.

Stiglitz zauważa, że pogłębiona nauka ekonomii wyłącznie w oparciu o podręczniki akademickie, zbliża studentów to myślenia w kategoriach modeli ekonomicznych, oddalając ich tym samym od rzeczywistości [Stiglitz 2011: 315]. Z drugiej zaś strony, w czasie przeprowadzania dyskusji przez studentów w trakcie seminariów ekonomicznych, niektórzy z nich przekazują innym wyłączenie swoje obserwacje, nie odwołując się w żaden sposób do teorii. I tak np. kryzys z 2007 r. tak silnie oddziaływał na postrzeganie rzeczywistości przez ludzi, że argumenty wymieniane przez studentów w czasie zajęć przypominały te, powszechnie znane z mass mediów. Dlatego też Day i in. zaproponowali, aby z uwagi na wpływ kryzysu na rynku subprime na poziom życia społeczeństw, władze odpowiedzialne za rozwój edukacji przeanalizowały zarówno treści przekazywane studentom, jak i sposób ich przekazu. W związku z powyższym interdyscyplinarne podejście w nauczaniu ekonomii może wzbudzić zainteresowanie studentów i obudzić ich wrażliwość [Day i in. 1997]. Poprzez prezentację za pomocą obrazów pewnych abstrakcyjnych koncepcji, film może uwypuklić je z większą dozą realizmu i ukazać zastosowanie w odmiennych sytuacjach [Champoux 1999: 206-228].

Według Golemana [1996: 559], z uwagi na to, że obcowanie ze sztuką wpływa na nasze emocje w naturalny i przyjemny sposób, wykorzystanie filmów, literatury, muzyki i malarstwa może zaowocować wytworzeniem właściwego środowiska sprzyjającego zwiększeniu aktywności i wzrostu zainteresowania w grupie studentów. Z kolei doświadczenia Sextona [2006: 406-417] 
wykazują, że wykorzystanie filmów w procesie nauczania ekonomii na poziomie studiów licencjackich przekłada się na poprawę pamięci oraz rozwój wyobraźni w badanej grupie studentów. W innym przypadku zastosowanie różnych technik prezentowania materiału przyczynia się do wzrostu zdolności uczenia się, utrzymania koncentracji oraz lepszego zapamiętywania materiału pośród studentów o tzw. pamięci wzrokowej [Parker 2009: 129-134]. Rezultaty Sextona potwierdzają tym samym wcześniejsze badana Maynarda [1971], gorącego zwolennika aplikowania różnego rodzaju mediów podczas zajęć. Ten ostatni uważał, że wzbogacony o przekazy medialne wykład staje się bardziej atrakcyjny, powodując tym samym, że studenci, nie nudzą się w trakcie wykładów. Zdaniem Gaiacalone i Jurkiewicza [2001: 79-87] studenci łatwiej zapamiętywali koncepcje osadzone w filmowej fabule niż materiał teoretyczny. Buchanan i Huczyński [2004: 312-323] argumentują, że narracja filmowa zawiera w sobie pewien komponent teoretyczny, który poprzez sekwencje wydarzeń może wyjaśnić określone rezultaty pewnych procesów, ich związek z akcją oraz konsekwencjami działań. Filmy fabularne mogą służyć do integracji liberalnych koncepcji sztuki i procesów realnych a także stanowić most ponad luką pomiędzy wiedzą prezentowaną w czasie tzw. edukacji ogólnej, a kursami zawodowymi [McAdams i Duclose 1999: 57-67].

Według Boatmana i in. [2008: 39-48] uczenie określonych zagadnień z ekonomii, za pomocą projekcji filmów przyczynia się do wzrostu tempa zapamiętywania wśród studentów. Ponadto projekcje filmów w trakcie wykładu przekładają się na ożywienie dyskusji wśród studentów, która to staje się integralną częścią zajęć. W ten sposób studenci mogą skonfrontować swoje doświadczenia $\mathrm{z}$ wydarzeniami ukazanymi $\mathrm{w}$ trakcie pokazu [Mixton 2010: 110113], a także wzbogacić poznawcze aspekty ekonomii o doznania i emocje, jakich doświadczyli w czasie projekcji [Macy i Terry 2008: 31-51 oraz Stratton i in. 2011: 1-27].

\section{OBRAZ CHCIWOŚCI NA RYNKACH FINANSOWYCH ZARYSOWANY W WYBRANYCH ANGLOSASKICH FILMACH FABULARNYCH}

Pierwsza, niemal naukowa definicja chciwości pojawia się w filmie „Wall Street" [reż. Oliver Stone 1987], kiedy to w czasie walnego zgromadzenia akcjonariuszy papierni Teldar, Gordon Gekko wygłasza swój monolog: „Chciwość, z braku innego słowa, jest dobra. Chciwość jest w porządku. Chciwość sprawdza się. Chciwości oczyszcza, dociera do sedna i uosabia ducha ewolucji. Chciwość wszelkiego rodzaju: życia, pieniędzy, miłości, wiedzy wskazywała ludzkości drogę do góry. Zapamiętajcie moje słowa. Chciwość uratuje nie tylko 
papiernię Teldar, ale też źle zarządzaną firmę zwaną Stanami Zjednoczonymi”. Gordon Gekko wypowiadając te słowa dążył do przejęcia kontroli nad papiernią Teldar, którą chciał podzielić na mniejsze części, a następnie sprzedać. Podobne rozumienie chciwości spotkać można także w filmie „Cudze pieniądze” [,Other people's money”, reż. Norman Jewison1991] czy też w „Pretty woman” [reż. Garry Marshall 1990]. W tym pierwszym obrazie Lawrence Garfield dąży do wrogiego przejęcia spółki New England Wire and Cable Co., a następnie jej likwidacji. Nie interesuje go los pracowników New England Wire nad Cable Co. Kieruje się czystą chciwością, konsekwentnie dążąc do celu. Z kolei bohater filmu „Pretty woman”, Edward Lewis specjalizuje się we wrogich przejęciach firm mających problemy finansowe. Po przejęciu firmy, dokonuje sprzedaży jej zorganizowanych części, a suma środków uzyskanych jako wpływy ze sprzedaży tych części przewyższa cenę zakupu całej firmy. Motyw przejęcia firmy, wrogiego lub przyjaznego pojawia się także w pierwszym, znaczącym obrazie poświęconym rynkom finansowym, tj. filmie „Wall Street”. O ile Gordon Gekko stara się o przejecie firmy Blue Star w celu jej likwidacji i wyprzedaży aktywów, o tyle Larry Wildman zamierza pomóc tej firmie i przeprowadzić jej restrukturyzację, podobnie jak wcześniej udało mu się to zrobić m.in. z hutą Anacot. To właśnie chciwość Gordonna Gekko jest powodem zerwania umowy, jaką zawarł z przedstawicielami firmy Blue Star, aby następnie, nie informując ich o tym, zmienić swoje zamierzania co do przyszłości tej firmy, z ogłaszanej pierwotnie restrukturyzacji po chęć sprzedaży jej zorganizowanych części. W drugiej części filmu „Wall Street” tj. „Wall Street. Pieniądz nie śpi” [,Wall Street: money never sleeps", reż. Oliver Stone 2010], widzowie dowiadują się, że plany Larry’ego Wildmana w stosunku do firmy Blue Star ziściły się. Linie zostały zrestrukturyzowane, a po pewnym czasie, kiedy odniosły już sukces, zostały sprzedane z zyskiem innemu właścicielowi. Doskonałą zależność między postępowaniem ludzi a pieniędzmi, nawiązującą do chciwości, zaprezentował w filmie „Wall Street” makler Lou Mannheim: „Pieniądze mają to do siebie, że zmuszają nas do wstrętnych uczynków”. Na rynkach finansowych, można wymienić całą gamę wstrętnych uczynków, wśród których, jednym z najczęściej spotykanych jest insider tradig, tj. wykorzystanie informacji poufnych ${ }^{3}$. Zagad-

\footnotetext{
${ }^{3}$ Informacja poufna - informacja zdefiniowana w art. 154 Ustawy z dnia 29 lipca 2005 r. o obrocie instrumentami finansowymi, czyli informacja określona w sposób precyzyjny informacja dotycząca, bezpośrednio lub pośrednio, jednego lub kilku emitentów instrumentów finansowych, jednego lub kilku instrumentów finansowych albo nabywania lub zbywania takich instrumentów, która nie została przekazana do publicznej wiadomości, a która po takim przekazaniu mogłaby w istotny sposób wpłynąc na cenę tych instrumentów finansowych lub na cenę powiązanych z nimi pochodnych instrumentów finansowych, przy czym dana informacja: 1) jest określona w sposób precyzyjny, wtedy gdy wskazuje na okoliczności lub zdarzenia, które wystąpiły lub których wystąpienia można zasadnie oczekiwać, a jej charakter w wystarczającym stopniu umożliwia dokonanie oceny potencjalnego wpływu tych okoliczności lub zdarzeń na cenę lub wartość
} 
nienie to zostało doskonale zilustrowane w wielu filmach poświęconych rynkom kapitałowym. I tak w filmie „Nieoczekiwana zmiana miejsc” [,,Trading places”, reż. John Landis 1983], uzyskanie informacji poufnych. tj. tajnego raport Departamentu Rolnictwa USA o planowanej wielkości zbiorów pomarańczy w Brazylii, posłużyło do przeprowadzenia krótkiej sprzedaży na rynku towarów, a konkretnie na rynku mrożonego soku pomarańczowego przez Luisa Winthorpe'a III i Billy'ego Valentine'a. O insider trading oskarżony zostaje główny bohater „Wilk z Wall Street” [,,The wolf of Wall Street”, reż. Martin Scorsese 2013], jak również bohaterka filmu „Partner” [,The Associate”, reż. Donald Patrie 1996] - Laurel Ayres, za co traci licencję maklera oraz bohaterowie filmu „Giełda za kratami” [„Buy and cell”, reż. Robert Boris 1987]. Informacjami poufnymi posługują się w celu osiągnięcia zysków również główne postacie obrazów: „Żądza bankiera” [„Le capital”, reż. Costa Gavras 2012] oraz „Rodzinny interes” [„,Family Business”, reż. Sidney Lumet 1989]. Należy jednak pamiętać, że dla Gordona Gekko informacja jest najcenniejszym towarem i dlatego też zamiast „rzucać strzałkami do tarczy” jak inni, on „... stawia jedynie na pewniaki”. Gloryfikuje wykorzystanie informacji poufnych namawiając Buda Foxa do posługiwania się nimi, cytując dzieło Sun Tzu „Szuka wojny” [2012]: „Każda bitwa ma zwycięzcę zanim się rozpocznie". Przed wykorzystaniem informacji poufnych stara się ostrzec Buda jego kolega Lou wyrażając to w sentencji „nie ma drogi na skróty". Jednak chciwość osiągnięcia sukcesu jest tak wielka, że Bud ignoruje te ostrzeżenia, podążając drogą ku przestępstwu. W drugiej części filmu „Wall Street” widzowie dowiadują się, że jednym z zarzutów, postawionym Gordonowi Gekko było m.in. wykorzystanie informacji poufnych.

Problematyka chciwości przedstawiona w filmie „Wilk z Wall Street” sięga daleko głębiej niż mogłoby się to pozornie wydawać. Otóż Stratton Oakmont stał się największą firmą działającą na rynku over the counter (OTC) w USA w okresie od końca lat 80. XX w. do 1996 r. W swoje karierze udało jej się przeprowadzić pierwsze oferty publiczne 35 spółek, w tym znanej z filmu firmy, należącej do Steve'a Maddena. W rzeczywistości działalność Stratton Oakmont była zbliżona do firmy typu ,pompuj i porzuć” (pump and dump) [Pump and Dump Schemes, 2001], które operują w segmencie firm śmieciowych,

instrumentów finansowych lub na cenę powiązanych z nimi pochodnych instrumentów finansowych; 2) mogłaby po przekazaniu do publicznej wiadomości w istotny sposób wpłynąć na cenę lub wartość instrumentów finansowych lub na cenę powiązanych z nimi pochodnych instrumentów finansowych, wtedy gdy mogłaby ona zostać wykorzystana przy podejmowaniu decyzji inwestycyjnych przez racjonalnie działającego inwestora (...) Spółka giełdowa na bezwzględny obowiązek przekazanie informacji poufnej raportem bieżącym do publicznej wiadomości [vide art. 56 Ustawy o ofercie publicznej (...)]. Definicja pochodzi ze strony internetowej: https://www.knf.gov.pl/ dla_rynku/Informacje_dla_podmiotow_nadzorowanych/Rynek_kapitalowy_info_dla_podmiotow/mar/ Informacja_poufna_q\&a.html, [dostęp: 19.01.2017]. Na rynkach finansowych innych krajów obowiązują inne definicje informacji poufnej. 
tj. o niskiej cenie jednej akcji. Ponadto działalność typu „pompuj i porzuć” polega na podtrzymywaniu sztucznie napompowanego kursu akcji śmieciowych, które zostały wcześniej nabyte przez udziałowców firmy i sprzedaży ich nowym klientom. W wielu przypadkach sztuczną zwyżkę uzyskuje się po podaniu spreparowanego sprawozdania finansowego sprzedawanej firmy. Innym sposobem jest stworzenie akcji firmy, które nie istnieją lub też tylko mają siedzibę, a nie prowadzą żadnej działalności gospodarczej. Zadaniem pracowników firmy typu „pompuj i porzuć” jest sprzedanie po jak najwyższych cenach akcji, klientom z którym się kontaktują. Sprzedawcy za pomocą różnego rodzaju socjotechnik starają się nakłonić osoby, do których dzwonią do zakupu pewnej partii akcji. Po sprzedaży dużej ilości akcji nowym klientom, kurs takich firm najczęściej załamuje się, podczas gdy oni ponoszą znaczne straty. Przykład działania takiej firmy został zaprezentowany również w filmie „Ryzyko” [„Boiler Room”, reż. Ben Younger 2000], wraz ze stosowanymi przez pracowników socjotechnikami. Socjotechnikami posługiwał się również Jordan Belfort, co jest doskonale widoczne w scenie, kiedy szkoli pracowników Stratton Oakmont, jak sprzedawać akcje w najbardziej efektywny sposób. W praktyce zasada działania firm „pompuj i porzuć" zbliżona jest do piramidy finansowej ${ }^{4}$. Jednak o ile w piramidzie finansowej wpłaty kolejnych klientów finansują wypłaty klientów, którzy przystąpili do piramidy w jej początkowej fazie działania, o tyle w firmach ,pompuj i porzuć" nie dopuszcza się aby klienci firmy sprzedawali nabyte akcje, kreując w ten sposób sztuczny popyt. Proceder ten jest dobrze widoczny w filmie „Ryzyko", natomiast nie został on we właściwy sposób zarysowany w „Wilku z Wall Street”. Obrazy „Wilk z Wall Street” i „Ryzyko” stanowią doskonałe studium przypadku firm, które specjalizują się w oszukiwaniu swoich klientów. Czasami ta kryminogenna działalność może stanowić tylko pewien dodatek do legalnej działalności takiej firmy, jednak doprowadza do ludzkich dramatów, takich jak przypadek Maxa Reynarda z filmu „Ryzyko”, który oszukańczej firmie powierzył oszczędności przeznaczone na budowę domu, zwiedziony wizją lukratywnych zysków, przedstawionych przez Setha Davisa.

Nieco inne podejście do kwestii chciwości i pieniędzy zaprezentował w filmie „Żądza bankiera” Marc Tourneuil, przypisując poniższe powiedzenie swojemu szefowi: „Pieniądz jest jak pies, który nie lubi głaskania. Chce tylko przynosić piłkę rzucaną mu coraz dalej”. W innym fragmencie filmu zauważa on, że „Ludzie myślą, że pieniądz to tylko narzędzie. Nieprawda. Pieniądz to twój pan. Im lepiej mu służysz, tym lepiej cię traktuje". Marc Tourneuil zdaje się stać na szczycie piramidy chciwości. W jeszcze innym fragmencie na pytanie żony „Po co ci tyle pieniędzy?”, błyskawicznie odpowiada: „A jest coś lepszego? Marc

${ }^{4}$ Schemat działania piramid finansowych został przedstawiony m.in. w: Zieliński [1997]. Jedną z najbardziej znanych piramid finansowych ostatnich lat, działająca w Polsce był Amber Gold. 
Tourneuil gotów jest wzbogacić się nawet kosztem zwalnianych pracowników. Otóż kiedy grupa finansowa Fenix zamierza przeprowadzić drastyczne redukcje zatrudnienia, zwane przez prezesa grupy, Marca Tourneila „ewaluacją”, przedstawia on grupie akcjonariuszy żądanie uzyskania nagrody w wysokości 3 tys. euro za każdego zwalnianego pracownika. W ten sposób chce on doprowadzić do wzrostu rentowności kapitału netto grupy finansowej Fenix do poziomu 20\% - z czym wiąże się uzyskanie przez niego kolejnej nagrody, wcześniej wynegocjowanej z grupą największych akcjonariuszy. Marc Tourneuil szacuje, że przy zwolnieniu 7 tys. pracowników grupy finansowej Fenix, cena akcji tej firmy na rynkach wzrośnie od $12 \%$ do $18 \%$, a przy redukcji personelu o 10 tys. osób - od $22 \%$ do $26 \%$. Zauważmy, że redukcja liczby pracowników banku o 10 tys. osób oznacza dla Marca Tourneuila nagrodę w wysokości $30 \mathrm{mln}$ euro. Ostatecznie akcjonariusze zgadzają się na 1 tys. euro w przypadku pracowników w wieku do 50 lat i na 1250 euro w przypadku pracowników w wieku powyżej 50 lat. Podanie do publicznej widomości planu zwolnień w Fenixie przekłada się na wzrost ceny akcji tej grupy na giełdzie w Nowym Jorku o 19\%, co oznacza dla prezesa Marca Tourneuila kolejny bonus w wysokości 2 mln euro. Doskonałą kwintesencją działania współczesnych banków, jest końcowe zdanie, jakie wygłasza Marc Tourneuil, na spotkaniu z akcjonariuszami: „Jestem waszym współczesnym Robin Hoodem. Nadal będę zabierał biednymi i dawał bogatym”. Zgromadzeni nagradzają te słowa owacją.

Nawiązanie do współczesnych definicji chciwości, tj. lat poprzedzających wybuch kryzysu w 2007 r. występują także w filmie „Wall Street. Pieniądz nie śpi”, Gordon Gekko w czasie prezentacji swojej książki, stwierdza, że obecnie chciwość stała się legalna, chociaż jest nico bardziej przyprawiona odrobiną zawiści. Jego zdaniem, to właśnie chciwość sprawia, że barman kupuje sobie trzy domy, na które go nie stać. To właśnie chciwość jest odpowiedzialna za to, że rodzice słuchaczy jego prelekcji biorą 250 tys. USD kredytu na dom wart 200 tys. USD, a za 50 tys. USD kupują sobie telewizor plazmowy, komórki i SUVa. Gekko nie może zrozumieć, dlaczego tych pięćdziesięciu tysięcy nie przeznaczają na kolejny dom? Jego zdaniem, to właśnie przez chciwość rząd USD obniżył stopy procentowe po 11 września 2001 r., aby Amerykanie znów mogli przeznaczać więcej środków na konsumpcję. Gekko prowadza pojęcie „sterydowej bankowości” odnosząc się do wysokich dźwigni finansowych stosowanych przez banki przed wybuchem kryzysu na rynku sub prime.

W drugiej części „Wall Street” inwestorzy otrzymują także kolejną lekcją nt. chciwości. Gekko posługuje się w tym przypadku „Tulipomanią”, a więc manią, która doprowadziła do niebotycznego wzrostu cen cebulek tulipanów w Holandii w XVII w. [Kindleberger 1999: 191-194]. W jej szczycie, za jedną cebulkę tulipana określonego gatunku można było nabyć kamienicę w Amsterdamie. Wkrótce potem ceny gwałtownie spadły, a wielu inwestorów straciło 
majątek życia. Na ścianie wynajmowanego przez Gekko apartamentu, widzowie mają możliwość podziwiać wykres cen jednej cebulki gatunku Semper Augustus, który do złudzenia przypomina swoim kształtem odwróconą literę „V”. Chciwość doprowadza do pogrążenia się Brettona Jamesa, który inwestował na swoje konto w czasie przejmowania jednego z banków przez Churchil Schwartz. Sam zresztą przyznaje „Chciałem zarobić. A kto nie chce?” W ten sposób Bretton James rujnuje swoją karierę tracąc jednocześnie zaufanie jednego z największych klientów banku - Juliego Steinhardta.

Pochwała chciwości wyrażona przez Gordona Gekko w filmie „Wall Street” i sama postać tego finansisty znalazła także swój wydźwięk w obrazie „,Wilk z Wall Street", kiedy to Jordan Belfort został porównany przez agenta FBI Patricka Denhama, właśnie do Gordona Gekko. Zresztą sam Belfort określał to, co działo się w jego firmie jako „orgię chciwości”. Był dumy z tego, że wyzwalał chciwość brokerów oraz z faktu, że tłumy niepokornych dzieciaków chciały u niego pracować. Dowiedziawszy się o zarobkach w firmie prowadzonej przez Belforta, często porzucali studia, aby tylko dostać się do tej wymarzonej pracy. Zanim jednak Belfort wykształcił swoją wizję chciwości, inne spojrzenie zostało mu przedstawione przez Marka Hanna'ego w czasie lunchu. Zdaniem tego ostatniego, to właśnie żerowanie na chciwości klientów firmy brokerskiej, pozwala maklerom uzyskiwać wysokie prowizje. Chodzi o to, że klientowi należy przedstawić wizję przyszłych zysków, jakie może osiągnąć kupując kolejne akcje. Belfort rozwija tę wizję, udoskonalając stosowane przez siebie techniki sprzedaży, doprowadzając je do perfekcji. Może Belfort nie artykułuje tego bezpośrednio w filmie, ale przesłanie płynące $\mathrm{z}$ tego obrazu jest oczywiste. Chciwość nie jest dobra. Jest najlepsza!

Pewnym pocieszeniem może być fakt, że bohater filmu „Pan Verdoux” [,Monsieur Verdoux”, reż. Charles Chaplin 1947], który aby utrzymać swoje lewarowane pozycje na giełdzie paryskiej, musi w tym celu posługiwać się pieniędzmi mordowanych kobiet, wcale nie zabija z chciwości. Morderstwo traktuje jako swoją profesję. Ma bowiem żonę i syna, których musi utrzymać. Również pobudki skłaniające Nicka Leesona,do prowadzenia nieautoryzowanych transakcji na koncie 88888 na giełdzie SIMEX, które doprowadziły do upadku Banku Barings, wynikały nie $\mathrm{z}$ chciwości ale $\mathrm{z}$ chęci odrobienia strat biura maklerskiego, jakie były księgowane na tym koncie [Spekulant („Rogue trader”), reż. James Dearden 1999 oraz Leeson 1997]. W wielu obrazach chciwość została napiętnowana. Jednym z najbardziej znanych film jest „Siedem” [,Seven”, reż. David Fincher 1995], w którym chciwy adwokat Eli Gould skazany został, przed zamordowaniem na wycięcie sobie jednego funta ciała. Do niego należało jedynie dokonanie wyboru, jaka to będzie część ciała. 


\section{OBRAZ CHCIWOŚCI NA RYNKACH FINANSOWYCH ZARYSOWANY W WYBRANYCH POLSKICH FILMACH FABULARNYCH}

Polskich filmów fabularnych, w których przewija się wątek finansowy, jak dotąd nakręcono niewiele. Nie mniej w tych kilku obrazach wyraźnie zarysowany został wątek chciwości. Wykorzystanie informacji poufnych ukazane zostało w filmie „Amok” oraz „Pierwszy milion”. W tym pierwszym obrazie uosobieniem chciwości jest prywatny inwestor Maksymilian Rybak (pseudonim Max). W jednej ze cen, jego dawna dziewczyna Julia, a obecnie żona prezesa zarządu jednej z firm notowanych na warszawskim parkiecie, prowokuje Maklera obsługującego inwestora nazywanego Rekinem. W czasie nieudanej próby zdobycia Juli przez tegoż maklera, Maksymilian z zimną krwią robi parze zdjęcia, które obiecuje zniszczyć, ale w zamian za ujawnienia składu portfela Rekina. Maksymilian w grze giełdowej posługuje się pieniędzmi pożyczonymi na wysoki procent od mafiosa o pseudonimie Bryła. Przeczuwając zbliżający się koniec hossy, Maksymilian jest gotów zagrać po raz ostatni o bardzo wysoką stawkę, tak aby w ten sposób uzyskać wysoką stopą zwrotu, zwrócić pieniądze Bryle i zachować dużą pulę środków dla siebie. W tym celu Maksymilian Rybak szantażuje Rekina, aby razem połączyli siły w celu spowodowania gwałtownego wzrostu jednej ze spółek notowanych na warszawskim parkiecie i znajdującej się już w portfelu Rekina, tj. Teximpexu. Maksymilian dysponuje bowiem pewnym dokumentem wskazującym na wykorzystywanie przez Rekina informacji poufnych w obrocie akcjami spółki Teximpex. Ostatecznie Maksymilian i Maciek Kwast (drugi z bohaterów filmu „Amok”), wspólnie z innymi inwestorami organizują tzw. „spółdzielnię”, której zadaniem jest wywindowanie ceny akcji Teximpexu. Organizowanie tego typu grup, sztucznie zawyżających lub zaniżających kurs walorów, jest zakazane przez prawo. W jednej ze scen filmu „Amok” zarysowany został również inny, kryminalny proceder, tj. wybieranie osób, które mogą jako pierwsze wejść do domu maklerskiego i nabyć sprzedawane w nim w procesie IPO akcje pewnej spółki. Tego typu zachowania miały miejsce w czasie hossy z lat 1993/1994, kiedy to obowiązywała zasada ,kto pierwszy, ten lepszy”, wg. której akcje spółki nabywali ci, którzy pierwsi pojawiali się w biurze maklerskim dokonującym sprzedaż tych walorów. Fascynację pieniędzmi przejawia też Maciej Kast, co jest doskonale widoczne w czasie sceny, w której rozkłada, na podłodze swojego mieszkania zarobione na giełdzie pieniądze. Jak sam mówi do swojej dziewczyny - Ewy: „... budzą szacunek”.

Z kolei bohaterowie drugiego polskiego obrazu „Pierwszy milion”, którego akcja obejmuje także rynki finansowe, kierowani chciwością, stosując określone socjotechniki (jak np. jak np. telefoniczne rozmowy ze swoimi współpracownikami udającymi kontrahentów, którzy nie byli zainteresowani kupnem obligacji 
i sugerowali kolejne obniżki cen zakupu tych papierów) zmuszają pracowników zakładów państwowych do sprzedaży obligacji zamiennych na akcje po cenie $70 \%$ ich wartości nominalnej. W następnej kolejności bohaterowie sprzedają je po $80 \%$ wartości albo zamieniają na akcje z kilkudziesięcioprocentową premią. W tym samym filmie, dwukrotnie pojawia się wątek wykorzystania informacji poufnych. W pierwszym przypadku, jeden z głównych bohaterów, Tomasz Frycz uzyskuje informację od pewnego wysoko postawionego urzędnika państwowego o nadchodzącym załamaniu na giełdzie, która ta pozwala mu zamknąć wszystkie pozycje przed spadkiem cen. Wcześniej cała trójka bohaterów filmu wykorzystuje informację poufną przekazaną przez maklera Witolda Hofmana o składzie portfela jednego z największych indywidulanych inwestorów i składanych przez niego zleceniach. Dzięki tym informacjom bohaterowie filmu szybko wzbogacili się, popadając jednak w kłopoty z mafią. W filmie „Pierwszy milion" powraca kwestia manipulowania listą osób, mogących nabyć akcje w pierwszej ofercie publicznej. I tak bohaterowie, podobnie jak i grupa inwestorów, związana z mafią, przez podstawione osoby, organizują nawet gigantyczną kolejkę społeczną, która zadaniem jest nabycie akcji spółki w procesie IPO.

W filmie „Układ zamknięty” [reż. Ryszard Bugajski 2013] widzowie stają się świadkami wrogiego przejęcia firmy Nawar przez przedstawicieli państwa (jednego z ministrów), prawa (prokuratorów) oraz urzędu skarbowego (naczelnika urzędu skarbowego), których zachowania niewiele różnią się od postępowania członków grup przestępczych. Rządząca nimi chciwość doprowadza do spadków cen akcji, notowanej na giełdzie spółki Nawar niemal do zera, a także do ludzkich tragedii, w tym m.in. do doprowadzenia do aresztowania dotychczasowych właścicieli filmy Nawar, próby popełnienia samobójstwa przez jednego z jej właścicieli - Piotra Maja. Po spadku cen akcji niemal do zera, stają się one celem przejęcia pewnej zagranicznej firmy inwestycyjnej, stanowiącej przykrywkę dla przedstawicieli państwa, prawa i urzędu skarbowego. Dotychczasowi właściciele Nawaru w zamian za możliwość wyjścia z aresztu muszą zrzec się posiadanych pakietów akcji na rzecz grupy organizującej wrogie przejęcie. Ponadto rodziny dotychczasowych właścicieli Nawaru zmuszone są do wyprzedaży swoich pakietów po niskich cenach, w celu zapewnienia aresztowanym członkom rodziny ochrony prawnej (np. Joanna Rybarczyk - żona Grzegorza). W konsekwencji działań przedstawicieli państwa, prawa oraz urzędu skarbowego, po niespłaceniu przez Nawar kolejnej raty leasingowej, firma zostaje zamknięta, a maszyny wywiezione zagranicę. Właściciele Nawaru, po wyjściu $\mathrm{z}$ więzienia, otrzymują propozycję zatrudnienia $\mathrm{w}$ zarządzie $\mathrm{w}$ jednej $\mathrm{z}$ duńskich firm, z którymi Nawar kooperował przed jego zamknięciem.

W kinematografii polskiej można ponadto znaleźć wiele filmów, z których określone sceny mogą zostać wykorzystane w procesie dydaktycznym. Warto tutaj wspomnieć o takich obrazach jak: „Ziemia obiecana” [reż. Andrzej Wajda 
1975], „Kariera Nikodema Dyzmy” [reż. Jan Rybkowski 1980], „Kariera Nikosia Dyzmy” [reż. Jacek Bromski 2002], „Va banque” [reż. Juliusz Machulski 1981], czy filmach, będących ekranizacją popularnych lektur szkolnych: „Lalka” [reż. Ryszard Ber 1977] i „Nad Niemnem” [reż. Zbigniew Kuźmiński 1986].

\section{PODSUMOWANIE}

W nauce ekonomii, a zwłaszcza finansów, uczucie chciwości jest jedną z kluczowych emocji. $Z$ jednej strony stanowi ono siłę napędową przedsiębiorczości, jak również ma istotny wpływ na rozwój rynków finansowych, a także na podstawy inwestorów na tym rynku. Może być czynnikiem pozytywnym, przyczyniającym się do rozwoju ludzkości i finansów, jednak często ujawnia się jej ciemna strona, destrukcyjna, prowadząca do ludzkich dramatów i tragedii. Jednym z zadań wykładowcy akademickiego jest sprowokowanie studentów do samodzielnego myślenia, analizowania faktów, zadawania pytań i poszukiwania odpowiedzi na nie. Jak to zostało pokazane w artykule, także problem chciwości, działania podejmowane pod wpływem tego uczucia oraz ekonomiczne, społeczne i psychologiczne konsekwencje tych działan, zaprezentowane w wybranych filmach fabularnych mogą stanowić doskonałą bazę dydaktyczną do ciekawych dyskusji akademickich, w czasie prowadzenia wykładów z rynków finansowych. Pokazy wyselekcjonowanych filmów lub określonych scen, powinny odbywać się w trakcie semestru, raz w tygodniu, najlepiej w kinie studyjnym. W ten sposób uczestnicy pokazów mają możliwość zaznajomienia się $\mathrm{z}$ treściami prezentowanymi w wyświetlanych filmach, co umożliwi im aktywny udział w wykładach czy też konwersatoriach. Dyskusja nt. obejrzanych przez słuchaczy obrazów prowadzić może do interesujących spostrzeżeń i wniosków, często odmiennych niż te, które są powszechnie znane w nauce ekonomii. Filmowe charaktery mogą stanowić sprzymierzeńców lub oponentów dyskutantów. Podobnie rzecz ma się z zachowaniem giełdowych bohaterów. Warto też zwrócić uwagę na odmienny sposób prezentacji chciwości przez różnych reżyserów, a także na podobieństwa i różnice konsekwencji powstałych w wyniku działań podjętych pod wpływem uczucia chciwości. Jak to zostało przedstawione $\mathrm{w}$ artykule, niektórzy $\mathrm{z}$ twórców filmowych gloryfikują to uczucie, podczas gdy inni skupiają się na wskazaniu konsekwencji działań, negatywnych lub pozytywnych. W związku z powyższym analiza problemu chciwości ukazanej w filmach fabularnych może być skutecznym narzędziem w procesie dydaktyki przedmiotów ekonomicznych, a w szczególności finansowych. 


\section{BIBLIOGRAFIA}

Bay D., Felton S., 2012, Using popular films as a teaching resource in accounting classes, American Journal of Business Education - March/April.

Berger J., Pratt C., 1998, Teaching business communications ethics with controversial films, „Journal of Business Ethics”, vol. 17, 16.

Boatman K., Courtney R., Lee W., 2008, See how they learn: The impact of faculty and student learning styles on student performance in introductory economics, „American Economist”, vol. $52,1$.

Braun C., 2011, Capitalism in sic westerns by John Ford, „Journal of Economic Education”, vol. $42,2$.

Buchanan D., Huczynski A., 2004, Images of influence: 12 angry men and thirteen days, „Journal of Management Inquiry”, vol. 13, 4.

Bumbus M., 2005, Using motion pictures to teach management: Refocusing the camera lens through the infusion approach to diversity, „Journal of Management Education”, vol. 29, 6.

Cardon P., 2010, Using films to learn about nature of cross-cultural stereotypes in intercultural business communication courses, „Business Communication Quarterly”, vol. 7, 3.

Champoux J., 1999, Film as a teaching resource, „Journal of Management Inquiry”, vol. 8, 2.

Day H., Foltz M., Heyse K., Marksbary C., Sturgeon M., Reed S., 1997, Teaching economics using children's literature, National Council on Economic Education, New York.

Dixit A., 2005, Restoring fun to game theory, „Journal of Economic Education”, vol. 36, 3.

Gaiacalone R., Jurkiewicz C., 2001, Lights, camera, action: Teaching ethical decision making through the cinematic experience, „Teaching Business Ethics”, vol. 5, 1.

Goleman D., 1996, Emotional intelligence, Bloomsbury, London.

Kindleberger C., 1999, Szaleństwo, panika, krach. Historia kryzysów finansowych. WIG-PRESS, Warszawa.

Leeson N., 1997, Lajdak na gietdzie, WIG-PRESS, Warszawa.

Leet D., Houser S., 2003, Economics goes to Hollywood: Using classic films and documentaries to create an undergraduate economics course, „Journal of Economic Education”, vol. 34, 4.

Macy A., Terry N., 2008, Using movies as a vehicle for critical thinking in economics and business, ,Journal of Economics and Economics Education Research”, vol. 9, 1.

Mallinger M., Rossy G., 2003, Film as a lens for teaching culture: Balancing concepts, ambiguity and paradox, „Journal of Management Education”, vol. 27, 5.

Maynard R., 1971, The celluloid curriculum: How to use movies in the classroom, Hayden, New York.

McAdams T., Duclose L., 1999, Teaching business ethics with computer-based media? A cautionary analysis, „Teaching Business Ethics”, vol. 3.

Mixton F., 2010, More economics in the movies: Discovering the modern theory of bureaucracy in scenes from Conspiracy and Valkyrie, ,Journal of Economics and Economic Education Research", vol. 11, 1.

Nofsinger J., 1995, Barbarians at the gate: A capstone corporate finance project, „Financial Practice and Education", vol. 5, 1.

Parker R., 2009, Watch this clip: Using films as an augmentation to lecture and class discussion, „Academy of Educational Leadership Journal”, vol. 13, 4.

Pump and Dump Schemes, 2001, U.S. Securities and Exchange Commission, March 12.

Serey T., 1992, Carpe Diem: Lessons about life and management from Dead Poets Society, „Journal of Management Educations”, vol. 16. 
Sexton R., 2006, Using short movie and television clips in the economics principles class, „Journal of Economic Education", vol. 37, 4.

Stiglitz J., 2011, Freefall: America, free markets, and the singing of the world economy, Papadopoulos, Athens.

Stratton M., Kass D., Rotenberry P., 2011, Affective events theater: Creating teaching, moments from film and television to explore emotions in the workspace, ,Journal of Academy of Business Education", vol. 12.

Tzu S., 2012, Sztuka wojny, Studio Emka.

Zieliński R., 1997, Kulisy piramid finansowych, Wydawnictwo Piramida, Warszawa.

\section{Akty prawne}

Ustawa z dnia 29 lipca 2005 r. o obrocie instrumentami finansowymi, Dz.U. 2005, nr 183, poz. 1538 z poźn. zm.

\section{Strony internetowe}

https://www.knf.gov.pl/dla_rynku/Informacje_dla_podmiotow_nadzorowanych/Rynek_kapitalowy_ info_dla_podmiotow/mar/Informacja_poufna_q\&a.html

\section{Filmy zagraniczne}

Cudze pieniądze (Other people's money), reż. Norman Jewison, Warner Bros 1991.

Giełda za kratami (Buy and cell), reż. Robert Boris, Empire Pictures 1987.

Nieoczekiwana zmiana miejsc (Trading places), reż. John Landis, Paramount Pictures 1983.

Pan Verdoux (Monsieur Verdoux), reż. Charles Chaplin, Charles Chaplin Production 1947.

Partner (The Associate), reż. Donald Patrie, Hollywood Pictures 1996.

Pretty woman (Pretty woman), reż. Garry Marshall, Touchstones Pictures 1990.

Rodzinny interes (Family Business), reż. Sidney Lumet, Gordon Company 1989.

Ryzyko (Boiler Room), reż. Ben Younger, New Line Cinema 2000.

Siedem (Seven), reż. David Fincher, Cecchi Gori Pictures, New Line Cinema 1995.

Spekulant (Rogue trader), reż. James Dearden, Granda Film Productions 1999.

Wall Street (Wall Street), reż. Oliver Stone, Twentieth Century Fox Film Corporation 1987.

Wall Street: pieniądz nie śpi (Wall Street: money never sleeps), reż. Oliver Stone, Twentieth Century Fox Film Corporation 2010.

Wilk z Wall Street (The wolf of Wall Street), reż. Martin Scorsese, Paramount Pictures 2013.

Żądza bankiera (Le capital), reż. Costa Gavras, The Buremu 2012.

\section{Filmy polskie}

Amok, reż. Natalia Koryncka-Gruz, Fokus Film 1998.

Kariera Nikodema Dyzmy, reż. Jan Rybkowski, Zespół Filmowy „Silesia”, 1980.

Kariera Nikosia Dyzmy, reż. Jacek Bromski, Vision Film Distribution 2002.

Lalka, reż. Ryszard Ber, Zespół Filmowy „Pryzmat” 1977.

Nad Niemnem, reż. Zbigniew Kuźmiński, Syrena EG 1986.

Pierwszy milion, reż. Waldemar Dziki, Pleograf 2000

Układ zamknięty, reż. Ryszard Bugajski, Filmicon 2013.

Va banque, reż. Juliusz Machulski, Studio Filmowe „Kadr” 1981.

Ziemia obiecana, reż. Andrzej Wajda, Zespół filmowy „X” 1975. 


\title{
THE APOTHEOSIS OF GREED IN THE FINANCIAL MARKETS IN THE SELECTED FEATURE FILMS
}

\begin{abstract}
Nowadays, in economic education, especially in Western Europe and the USA, it is becoming increasingly important to use feature films to illustrate: specific economic processes and phenomena, the behavior of investors in financial markets, as well as financial, social and psychological consequences of these behaviors. The paper discusses the fragments of selected films, foreign and Polish, which relate to the greed of investors in the financial markets or refer to their attitude to money. Fragments of these films, as well as other images can be used in the teaching process and during specialized courses in broadly understood finance.
\end{abstract}

Keywords: economic education, financial markets, greed, movie in education process.

Przyjęto/Accepted: 04.05.2017

Opublikowano/Published: 30.09.2017 